DOI: https://doi.org/10.24127/ajpm.v10i4.4092

\title{
DESAIN VIDEO PEMBELAJARAN MATEMATIKA MATERI TURUNAN FUNGSI
}

\author{
Fitriyani Hali $^{1 *}$, Farman ${ }^{2}$ \\ ${ }^{1 *, 2}$ Universitas Sembilanbelas November Kolaka, Kolaka, Indonesia \\ ${ }^{*}$ Corresponding author. Jl. Pemuda No 339, Kolaka, Indonesia \\ E-mail: $\quad$ fitriyanihali@gmail.com ${ }^{1 *}$ \\ farman.math@yahoo.co.id ${ }^{2)}$
}

Received 06 August 2021; Received in revised form 16 September 2021; Accepted 15 December 2021

\begin{abstract}
Abstrak
Penelitian ini bertujuan untuk mendesain video pembelajaran matematika materi turunan fungsi yang layak digunakan bagi siswa SMA Kelas IX. Metode penelitian yang digunakan dalam penelitian ini adalah jenis penelitian pengembangan. Penelitian pengembangan merupakan penelitian yang berorientasi untuk menghasilkan produk tertentu dan menguji kelayakan produk tersebut. Desain video pembelajaran materi turunan dilakukan dengan langkah 4-D yaitu langkah define (pendefinisian), design (perancangan) develop (pengembangan) dan disseminate (penyebaran). Subjek uji coba terbatas penelitian ini adalah siswa kelas XI SMA Negeri 10 Kendari yang berjumlah 21 siswa. Instrumen yang digunakan dalam penelitian ini berupa angket lembar validasi dan angket respon siswa yang disusun dalam google form. Hasil validasi ahli materi dan ahli media menunjukkan bahwa desain video pembelajaran materi turunan berada dalam kriteria sangat valid. Hasil dari rerata indikator respon siswa yang terdiri atas fungsi dan manfaat, penyajian video serta bahasa dan tipografi menunjukkan persentase $87,3 \%$ yang berarti respon siswa menunjukkan sangat positif terhadap desain video pembelajaran yang dikembangkan. Dengan demikian video pembelajaran matematika materi turunan fungsi layak digunakan sebagai media belajar interaktif secara mandiri di sekolah atau di rumah dalam rangka menarik minat siswa dan memudahkan siswa dalam memahami turunan fungsi.
\end{abstract}

Kata kunci: Matematika; turunan fungsi; video pembelajaran.

\begin{abstract}
This study aims to design a mathematics learning video for derivative material that is suitable for use for class IX high school students. The research method used in this research is development research. Development research is research that is oriented to produce certain products and test the feasibility of these products. The design of the derived material learning video is carried out in a 4-D step, namely the define, design develop and disseminate. The subjects of the limited trial of this study were students of class XI SMA Negeri 10 Kendari, totaling 21 students. The instrument used in this study was a questionnaire validation sheet and student response questionnaire compiled in google form. The results of the validation of material experts and media experts show that the design of the derived material learning video is within the valid criteria. The results of the average student response indicators consisting of functions and benefits, video presentation as well as language and typography showed a percentage of $87.3 \%$ which means that responses showed a very positive attitude towards the learning video design developed. Thus the mathematics learning video for derivative is appropriate to be used as media for independent interactive learning at school or at home in order to attract students' interest and make it easier for students to understand derivatives.
\end{abstract}

Keywords: derivative; learning video; mathematics.

This is an open access article under the Creative Commons Attribution 4.0 International License 
DOI: https://doi.org/10.24127/ajpm.v10i4.4092

\section{PENDAHULUAN}

Perkembangan

teknologi

informasi dan komunikasi saat ini telah memberikan pengaruh dan kemajuan terhadap dunia pendidikan. Salah satu teknologi informasi yang ikut berperan dalam kemajuan dan memfasilitasi pendidikan saat ini adalah pembelajaran daring. Pembelajaran daring merupakan bentuk layanan pendidikan melalui belajar dari rumah selama masa pandemi covid-19. Hal ini sesuai Surat Edaran Menteri Pendidikan dan Kebudayaan Republik Indonesia Nomor 4 Tahun 2020 tentang pelaksanaan kebijakan pendidikan dalam masa darurat penyebaran covid-19 menyatakan untuk memenuhi hak peserta didik dalam pembelajaran di masa pandemi covid-19, penyelenggaraannya dilakukan melalui belajar dari rumah baik secara luring atau daring.

Fenomena pembelajaran dari rumah yang dilaksanakan selama covid19 tidak sesuai yang diharapkan. Berdasarkan survei yang dilakukan kemdikbud diperoleh bahwa mayoritas siswa kesulitan memahami pelajaran dengan rincian kesulitan memahami pelajaran mencapai $69,1 \%$ siswa, sebanyak $52,7 \%$ siswa kurang konsentrasi dan sebanyak 54,0\% siswa merasa bosan terhadap kegiatan yang dilaksanakan guru dalam pembelajaran. Hal ini disebabkan karena cara belajar siswa dari rumah, siswa lebih dominan mengerjakan soal-soal tugas dari guru $(86,6 \%)$ daripada belajar interaktif bersama guru secara daring $(38,8 \%)$ (Muhammad, 2020).

Rendahnya partisipasi peserta didik dalam pembelajaran interaktif secara daring karena penggunaan media/aplikasi dan desain pembelajaran daring yang diterapkan kurang tepat. Hal ini sejalan dengan kondisi di SMA Negeri 10 Kendari dimana partisipasi siswa dalam kegiatan pembelajaran rendah. Kegiatan pembelajaran lebih didominasi pemberian materi dan tugas dari guru oleh siswa melalui grup WhatsApp dan buku cetak matematika sekolah siswa. Hal ini menjadi solusi yang cocok karena mudah digunakan dan diakses oleh guru dan siswa. Tetapi hal ini tidak memberikan sentuhan inovasi, mendukung pembelajaran interaktif dan minat siswa dalam semangat belajar secara daring. Hal ini dapat memberikan dampak pada rendahnya pemahaman matematis siswa terhadap pelajarannya terutama matematika. Salah satu materi yang masih dirasa rumit oleh siswa sekolah menengah adalah turunan fungsi (Fatmanissa et al., 2019).

Mencermati kondisi tersebut, diperlukan adanya pemanfaatan media yang dapat memfasilitasi proses pembelajaran daring secara maksimal. Media yang efektif digunakan dalam pembelajaran daring adalah video pembelajaran (Parlindungan et al., 2020; Nurfadhillah et al., 2021). Istilah video berasal kata vidi atau visum dengan arti melihat atau mempunyai kemampuan melihat. Video memberikan satu cara penyampaian informasi secara langsung dan menarik bagi yang melihatnya. Video merupakan suatu media yang baik dan akan memberikan pengalaman baru (Fadhli, 2015). Video pembelajaran berbeda dengan buku guru dan buku siswa sehingga cukup efektif untuk digunakan sebagai suplemen dalam pembelajaran yang mampu menjangkau untuk subjek dalam jumlah besar (Agustiningsih, 2015). Penggunaan media video pembelajaran mampu menyalurkan pesan, perhatian, dan kemauan siswa dalam pembelajaran. Video pembelajaran dalam proses belajar matematika dapat memberikan 
pengaruh positif secara psikologis terhadap siswa (Kurniadi, 2017).

Video pembelajaran memiliki keunggulan dibanding dengan media yang lain. Alamsyah et al., (2018) mengungkapkan bahwa video memiliki kemampuan menghasilkan gambar dan suara dalam menjelaskan konsep, proses dan mengajarkan keterampilan, dan mempengaruhi sikap. Agustiningsih (2015) menambahkan bahwa video pembelajaran dapat digunakan secara klasikal ataupun individual yang memberikan kelebihan dalam penyajian objek lebih detail dibandingkan media cetak. Video pembelajaran dapat merangsang aktivitas dan mempermudah siswa dalam menangkap materi dari guru (Wardono et al., 2016). Selain itu video pembelajaran juga dapat dimanfaatkan sebagai materi suplemen dalam pemahaman konsep matematika (Farman \& Chairuddin, 2020) untuk mengimbangi jam pelajaran yang tidak berimbang dalam pelajaran matematika (Saloko et al., 2013)

Beberapa penelitian menunjukkan penggunaan video pembelajaran memiliki pengaruh yang signifikan dalam memfasilitasi hardskill dan softskill siswa. Penggunaan video pembelajaran memiliki pengaruh terhadap peningkatan partisipasi belajar matematika siswa dalam pembelajaran daring (Ferawati, 2021). Penggunaan video pembelajaran matematika memiliki pengaruh $100 \%$ terhadap pemahaman konsep, $100 \%$ terhadap motivasi Belajar, $100 \%$ terhadap kemampuan komunikasi matematis, $75 \%$ terhadap kemampuan pemecahan masalah matematis, $80 \%$ terhadap penalaran matematis dan $66,7 \%$ terhadap kemampuan berfikir kritis matematis (Anjarsari, 2020). Penerapan media video pembelajaran berpengaruh pada kegiatan pembelajaran di kelas dan bermanfaat dalam meningkatkan prestasi belajar siswa (Nasrum \& Herlina, 2019).

Hasil penelitian Gusmania \& Dari, (2018) juga menunjukan bahwa ada perbedaan pemahaman konsep siswa dalam penerapan video pembelajaran dibadingkan tidak menggunakan video pembelajaran. Penggunaan media video pembelajaran memotivasi peserta didik dan memberikan persepsi positif terhadap pembelajaran Matematika (Purwanti, 2015). Respon dan minat siswa dalam kegiatan pembelajaran sangat baik (Suseno et al., 2020). Pengunaan media video pembelajaran mampu memberikan peningkatan hasil belajar matematika (Kurniadi, 2017).

Dengan demikian, perlu dikembangkan media video pembelajaran sebagai suatu inovasi pembelajaran yang dapat mengatasi masalah-masalah pembelajaran dalam matematika, khususnya materi turunan fungsi. Dengan adanya penelitian ini diharapkan dapat menyediakan video pembelajaran meningkatkan minat dan pemahaman matematis bagi siswa dalam pembelajaran matematika.

\section{METODE PENELITIAN}

Penelitian ini merupakan jenis penelitian pengembangan. Penelitian pengembangan merupakan penelitian yang berorientasi untuk menghasilkan produk tertentu dan menguji kelayakan produk tersebut. Desain penelitian pengembangan ini menggunakan model 4-D yang terdiri atas 4 langkah yaitu define, design, development dan disseminate. Tahap disseminate dilakukan hanya sebatas pada upload video di situs youtube. Kegiatan uji coba secara luas belum dilakukan karena adanya keterbatasan waktu untuk melaksanakannya. Dengan demikian, 
produk yang dihasilkan belum memenuhi kriteria efektif dalam jangkauan yang luas sehingga produk belum bisa disebarkan.

Langkah define yaitu pendefinisian ketentuan dalam pembelajaran yang digunakan sebagai dasar dalam mengembangkan media pembelajaran. Langkah ini terdiri atas analisis awal-akhir, konsep, tugas dan perumusan tujuan pembelajaran (Muna et al., 2017).

Langkah design yaitu merancang video pembelajaran untuk memberikan solusi terhadap masalah yang ditemukan dalam pembelajaran. Hal-hal yang dilakukan dalam langkah ini berupa pembuatan video pembelajaran yang tepat dan format yang sesuai. Pada langkah ini akan diperoleh video pembelajaran awal yang akan diuji terelebih dahulu pada langkah development.

Tahap development yaitu kegiatan untuk melakukan tes video pembelajaran melalui validasi dan uji coba terbatas. Validasi dilakukan oleh ahli media dan ahli materi. Pada akhir penilaian, ahli/validator juga memberikan komentar sebagai sebagai saran dalam upaya revisi kekurangankekurangan dalam media. Ujicoba terbatas dilakukan dengan pemberian video kepada siswa dan menilainya melalui angket (Muna et al., 2017). Tahap pengembangan video pembelajaran disajikan pada Gambar 1 .

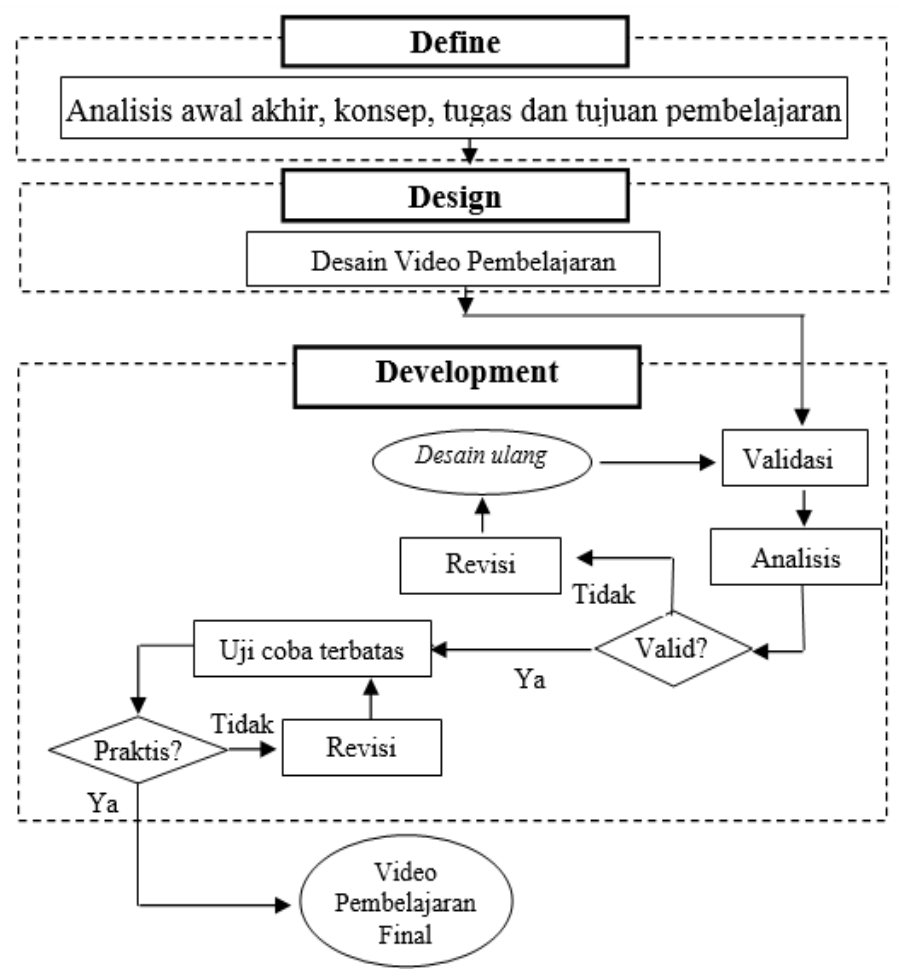

Gambar 1. Prosedur penelitian

Subjek penelitian dalam penelitian pengembangan ini adalah siswa kelas XI SMA Negeri 10 Kendari pada Tahun Ajaran 2020/2021. Instrumen pengumpulan data dalam penelitian ini terdiri atas lembar validasi dan angket respon siswa. Lembar validasi terdiri dari lembar validasi media dan materi 
yang diberikan kepada ahli media dan materi untuk dinilai. Hasil penilaian validasi bertujuan untuk memeproleh data tentang kualitas video pembelajaran yang dikembangkan. Sedangkan angket respon siswa digunakan untuk memperoleh informasi data siswa dari kepraktisan video pembelajaran yang telah disusun. Respon siswa memuat indikator yang menunjukkan fungsi dan manfaat video, penyajian video serta bahasa dan tipografi video pembelajaran bagi siswa.

Analisis data dalam penelitian ini dilakukan berdasarkan data yang diperoleh yaitu data hasil validasi dan data respon siswa. Aspek yang dinilai dalam validasi terdiri atas format/penyajian, isi, serta bahasa dan suara. Data hasil validasi diperoleh setelah menuliskan penilaiannya terhadap desain video yang dikembangkan pada lembar validasi. Penilaian para ahli dianalisis dengan menentukan rerata setiap kriteria dan rerata setiap aspek pada lembar validasi. Rerata ini kemudian ditotalkan secara keseluruhan yang kita sebut sebagai rerata total. Selanjutnya, rerata total yang dinilai validator disesuaikan dengan kriteria kevalidan. Media video pembelajaran layak digunakan jika hasil penilaian validator minimal berada pada kategori valid (Farman, 2020). Adapun kriteria kevalidan disajikan pada Tabel 1.

Tabel 1. Kriteria Kevalidan

\begin{tabular}{cc}
\hline Interval & Kriteria \\
\hline $4 \leq V R \leq 5$ & Sangat Valid \\
$3 \leq V R<4$ & Valid \\
$2 \leq V R<3$ & Kurang Valid \\
$1 \leq V R<2$ & Tidak Valid \\
\hline
\end{tabular}

Respon siswa terhadap penggunaan video dianalisis berdasarkan indikator fungsi dan manfaat, penyajian video serta bahasa dan tipografi. Respon siswa (RS) dianalisis dengan menetukan persentase respon siswa yang dirumuskan sebagai berikut:

$$
R S=\frac{J S P S}{S M} \times 100 \% \ldots
$$

Keterangan:

JSPS = Jumlah skor perolehan siswa

$\mathrm{SM}=$ Skor maksimum

Hasil persentase kemudian disesuaikan dengan kriteria yang ditetapkan, seperti pada Tabel 2. Media video pembelajaran layak digunakan jika respon siswa minimal berada pada kategori positif.

\section{Tabel 2. Kriteria Respon}

\begin{tabular}{cc}
\hline Interval & Kriteria \\
\hline $85 \%<\mathrm{RS} \leq 100 \%$ & Sangat Positif \\
$70 \%<\mathrm{RS} \leq 85 \%$ & Positif \\
$50 \%<\mathrm{RS} \leq 70 \%$ & Kurang Positif \\
$0 \% \leq \mathrm{RS} \leq 50 \%$ & Negatif \\
\hline
\end{tabular}

\section{HASIL DAN PEMBAHASAN}

Desain video pembelajaran materi turunan dilakukan dengan langkah 3-D yang diadaptasi dari langkah 4-D. Langkah-langkah dalam memproleh video pembelajaran yang layak digunakan melalui define (pendefinisian), design (perancangan) dan development (pengembangan).

\section{Define}

Langkah define dilakukan melalui analisis awal-akhir, analisis konsep, analisis tugas, dan analisis tujuan pembelajaran. Pada analisis awal-akhir, diperoleh informasi dari siswa bahwa pembelajaran yang dilaksanakan guru dalam pembelajaran daring belum dapat memberikan motivasi dan kurang memfasilitasi keberagaman modalitas belajar siswa. Guru hanya memberikan materi dan tugas yang terdapat pada buku paket siswa dengan sekali-kali masuk pada zoom. Siswa masih banyak yang sulit 
memahami penjelasan yang terdapat dalam buku paket, sehingga siswa mencari sendiri materi yang relevan diinternet. Oleh karena itu, perlu didesain media video pembelajaran matematika yang interaktif, variatif serta dapat diakses kapan saja dan dimana saja (Astika, et al. 2019). Dengan adanya media video sebagai pendukung dalam pembelajaran siswa dapat memberikan kebebasan pada siswa untuk belajar sesuai modalitas yang dimilikinya sehingga materi pembelajaran lebih mudah diserap oleh siswa (Farman et al., 2021).

Analisis konsep dilaksanakan dengan menelaah dan menentukan konsep-konsep yang akan dipelajari oleh siswa. Konsep-konsep yang dipelajari mengacu pada kurikulum 2013 untuk pelajaran matematika kelas XI SMA. Konsep yang akan didesain dalam video pembelajaran ini adalah turunan fungsi.

Analisis tugas ditujukan untuk mengidentifikasi tugas siswa yang mengacu pada kompetensi dasar dan indikator capaian hasil belajar siswa. Adapun kompetensi dasar dan indikator capaian hasil belajar siswa yang akan diidentifikasi yaitu materi turunan fungsi yang meliputi konsep turunan, turunan fungsi aljabar, fungsi naik, fungsi turun, titik belok, fungsi maksimum, aplikasi turunan fungsi dan grafik fungsi.
Bagian akhir adalah merumuskan analisis tugas kedalam tujuan pencapaian hasil belajar. Adapun tujuan pembelajaran siswa dalam konsep turunan fungsi adalah siswa dapat menentukan konsep garis sekan dan garis singgung, persamaan garis singgung disuatu titik dan konsep turunan sebagai limit suatu fungsi, titik stasioner suatu fungsi dan kecekungannya dengan konsep turunan dan interval kemonotonan dan titik belok suatu fungsi dengan menggunakan konsep turunan.

\section{Design}

Langkah ini dilaksanakan dengan menyusun materi turunan fungsi yang telah disiapkan dalam bentuk video. Penyusunan video dibuat dengan menggunakan powerpoint dan direkam dengan aplikasi camtasia. Setiap video pembelajaran didahului dengan judul pada slide pertama, tujuan pembelajaran pada slide kedua, penyajian materi contoh soal dan penyelesaiannya pada slide-slide berikutnya serta penutup dan ucapan terimakasih pada slide terakhir.

Pada video pembelajaran pertama menyajikan konsep turunan fungsi dengan tujuan pembelajaran agar siswa dapat menemukan konsep garis sekan dan garis singgung, menentukan persamaan garis singgung pada suatu titik dan menentukan konsep turunan sebagai limit suatu fungsi. Adapun tampilan desain disajikan pada Gambar 2.

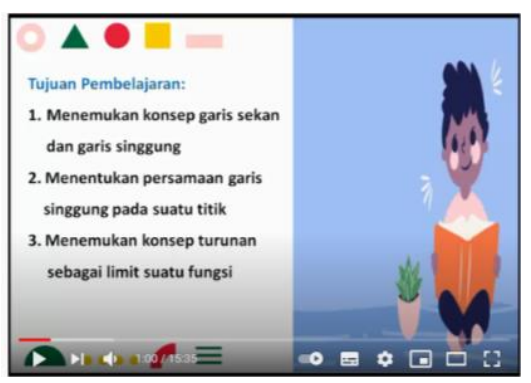

Gambar 2. Tampilan desain konsep turunan fungsi 
DOI: https://doi.org/10.24127/ajpm.v10i4.4092

Video pembelajaran kedua menyajikan turunan fungsi aljabar dengan tujuan pembelajaran agar siswa dapat mengetahui aturan-aturan turunan suatu fungsi dan menggunakan aturanaturan turunan untuk menetukan turunan suatu fungsi. Adapun tampilan desain disajikan pada Gambar 3.

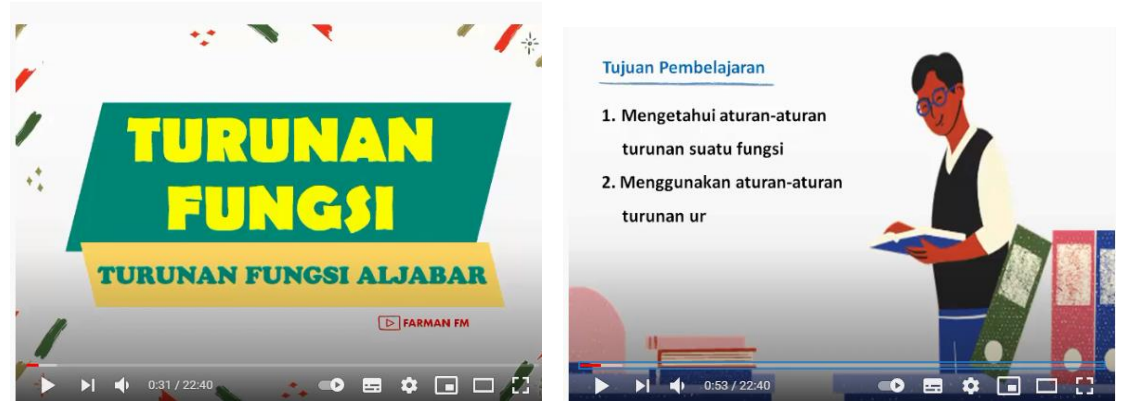

Gambar 3. Tampilan desain turunan fungsi aljabar

Video pembelajaran ketiga menyajikan konsep kemonotonan fungsi fungsi dengan tujuan pembelajaran agar siswa dapat menentukan titik stasioner suatu fungsi dan kecekungannya dan siswa dapat menentukan interval kemonotonan dan titik belok suatu fungsi dengan menggunakan konsep turunan. Adapun tampilan desain disajikan pada Gambar 4.
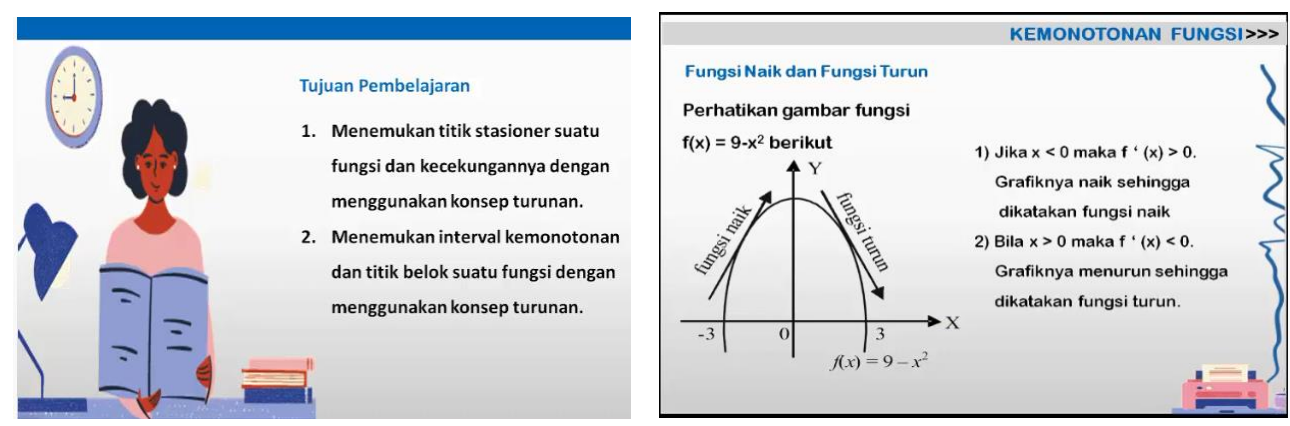

Gambar 4. Tampilan desain konsep kemonotonan fungsi

Video pembelajaran keempat menyajikan aplikasi turunan dan grafik fungsi dengan tujuan pembelajaran agar siswa dapat menyelesaikan masalah kehidupan sehari-hari yang berkaitan

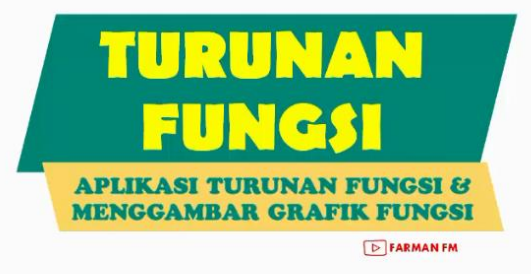

dengan turunan dan menganalisis dan menggambar grafik fumgsi dengan menggunakan konsep turunan. Adapun tampilan desain disajikan pada Gambar 5 .

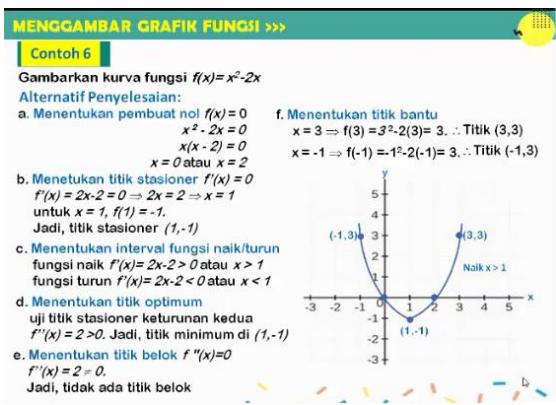

Gambar 5. Tampilan desain menggambar grafik fungsi 
DOI: https://doi.org/10.24127/ajpm.v10i4.4092

Selain desain video, disusun pula instrumen penilaian media video pembelajaran. Instrumen tersebut terdiri atas (1) lembar validasi materi dan media (2) angket respon peserta didik terhadap video pembelajaran.

\section{Development}

Desain media yang telah kembangakan kemudian dilakukan penilaian (validasi) oleh tiga validator. Validasi dilakukan dengan penyerahan lembar validasi yang telah disusun dalam bentuk google form beserta lampiran berupa video yang telah dikembangkan. Validator menilai dengan mengisi google form berdasarkan pernyataan pada lembar validasi. Hasil validasi materi disajikan pada Tabel 3.

Tabel 3. Hasil validasi materi

\begin{tabular}{lcc}
\hline Aspek Penilaian & Rerata & Kriteria \\
\hline Relevansi Materi & 4,46 & Sangat Valid \\
Kualitas Materi & 4,22 & Sangat Valid \\
$\begin{array}{l}\text { Bahasa dan } \\
\text { Tipografi }\end{array}$ & 3,56 & Sangat Valid \\
\hline Rata-rata total & 4,41 & Sangat Valid \\
\hline
\end{tabular}

Berdasarkan hasil validasi, materi yang dikembangkan termasuk dalam kategori sangat valid dengan rata-rata 4,41. Sedangkan jika ditinjau berdasarkan aspek penilaian terkait relevansi materi, kualitas materi serta bahasa dan tipografi juga menunjukan kategori valid.

Tabel 4. Hasil Validasi Media (Video)

\begin{tabular}{lcc}
\hline Aspek Penilaian & Rerata & Kriteria \\
\hline Fungsi dan manfaat & 4,17 & Sangat Valid \\
Visual & 4,33 & Sangat Valid \\
Audio & 4,33 & Sangat Valid \\
Pemrograman & 4,67 & Sangat Valid \\
Tipografi dan bahasa & 4,44 & Sangat Valid \\
\hline Rata-rata total & 4,38 & Sangat Valid \\
\hline
\end{tabular}

Rata-rata total penilaian validator terhadap video yang dikembangkan berada pada nilai 4,38 yang menunjukkan bahwa desain video sangat valid. Masing-masing aspek menunjukkan hal yang sama, masuk pada kategori sangat valid.

Dalam memberikan penilaian, validator materi dan ahli juga memberikan komentar berupa saran-saran yang dituliskan pada lembar validasi. Saran diberikan sebagai bahan revisi atas kekurangan yang terdapat dalam video yang dikembangkan. Saran-saran yang diberikan adalah slide yang memuat gambar grafik dibuat slide tersendiri agar dapat diperbesar dan keterangan grafik lebih jelas tulisannya. Selain itu, beberapa slide perlu diperbesar tulisannya agar dapat dibaca dengan jelas.

Setelah melakukan revisi atas masukan yang diberikan oleh validator, kemudian video pembelajaran diujicobakan secara terbatas kepada siswa. Uji coba terbatas dilaksanakan untuk memperoleh respon siswa terhadap desain video pembelajaran materi turunan sehingga hasilnya dapat dijadikan sebagai penyempurnaan video. Hasil analisis respon peserta didik disajikan pada Tabel 6.

Tabel 6. Hasil Respon Peserta didik

\begin{tabular}{lcc}
\hline \multicolumn{1}{c}{ Indikator } & $\begin{array}{c}\text { Rerata } \\
(\mathbf{\% )}\end{array}$ & Kriteria \\
\hline Fungsi dan manfaat & 83,8 & Sangat Positif \\
Penyajian Video & 86,2 & Sangat Positif \\
Bahasa dan Tipografi & 91,9 & Sangat Positif \\
\hline Rata-rata total & $\mathbf{8 7 , 3}$ & Sangat Positif \\
\hline
\end{tabular}

Hasil respon siswa pada indikator fungsi dan manfaat diperoleh rerata skor $83,8 \%$ dengan kriteria respon sangat positif. Respon peserta didik bahwa video ini memberikan manfaat dalam pembelajaran materi turunan fungsi karena video mampu membangkitkan motivasi peserta didik, mempermudah pemahaman materi, melatih kemandirian peserta didik. Indikator 
penyajian video diperoleh rerata persentase $86,2 \%$ dengan kriteria respon sangat positif. Respon sangat positif ini karena sebagian besar peserta didik menyukai tampilan dan warna, kejelasan gambar, kesesuaian kecepatan gerak video, volume suara, kecepatan audio dan musik pada video. Indikator bahasa dan tipografi diperoleh rerata persentase $91,9 \%$ dengan kriteria respon sangat positif. Hal ini karena peserta didik mengerti terhadap bahasa yang digunakan dalam video dan mudah membaca dengan jelas tulisan dan simbol yang digunakan dalam video. Hasil dari rerata indikator menunjukkan persentase $87,3 \%$ yang berarti respon siswa menunjukkan sangat positif terhadap desain video pembelajaran yang dikembangkan.

Berdasarkan penilaian ahli menunjukkan bahwa desain video pembelajaran materi turunan valid dan respon peserta didik berada dalam kriteria sangat positif. Hal ini berarti bahwa desain media video pembelajaran materi turunan layak untuk digunakan. Penelitian ini sejalan dengan penelitian Octavyanti (2021) yang menyatakan bahwa media video pembelajaran matematika layak digunakan sebagai upaya peningkatan pemahaman matematika siswa. Sejalan dengan Suryansah \& Suwarjo (2016) menyatakan bahwa video pembelajaran yang dikembangkan layak dan efektif dalam meningkatkan hasil belajar dan motivasi siswa. Video pembelajaran dianggap layak sebagai media pembelajaran karena (1) Waktu kelas yang digunakan lebih efisien, (2) pembelajaran lebih aktif dan interaktif, (3) penjelasan materi lebih jelas (4) memenuhi perbedaan gaya belajar siswa, dan (5) meminimalisir penggunaan model ceramah dalam pembelajaarn (Agustini \& Ngarti, 2020).

Secara teoritis, hasil penelitian ini dapat menjadi bahan referensi dan bahan kajian yang memberikan kontribusi pemikiran dalam mengembangkan media video pembelajaran yang bermanfaat dalam proses pembelajaran matematika. Secara praktis, penelitian ini memberikan penambahan referensi belajar bagi peserta didik untuk memahami materi, meningkatkan kemandirian belajar, meningkatkan minat dan motivasi belajar melalui bantuan video pembelajaran yang interaktif. Bagi pendidik, dapat menciptakan pembelajaran yang menarik dan menyenangkan sehingga mempermudah dalam penyampaian konsep materi ajar. Hal ini sejalan dengan pendapat Anjarsari \& Karim (2020) bahwa video pembelajaran matematika dapat memberikan suasana pembelajaran yang menyenangkan, menarik dan interktif sehingga siswa menjadi termotivasi untuk belajar.

Video pembelajaran materi turunan fungsi yang telah disempurnakan telah diunggah di youtube dengan empat sub materi. Konsep turunan fungsi dapat diakses pada youtube dengan link https://www.youtube.com/watch?v=SH KIpjUNE_Y\&t=179s . Turunan fungsi aljabar dapat diakses pada link https://www.youtube.com/watch?v=fKt Qx2gN6nM\&t=53s . Kemonotonan dan aplikasi turunan dapat dilihat pada https://www.youtube.com/watch?v=s50 WOL9JaeE\&t=22s. Sedangkan materi garfik fungsi daat diakses pada link https://www.youtube.com/watch?v=Qs BTuWqPCHk\&t=1401s . Produk akhir pengembangan video materi turunan fungsi disajikan pada Gambar 6. 


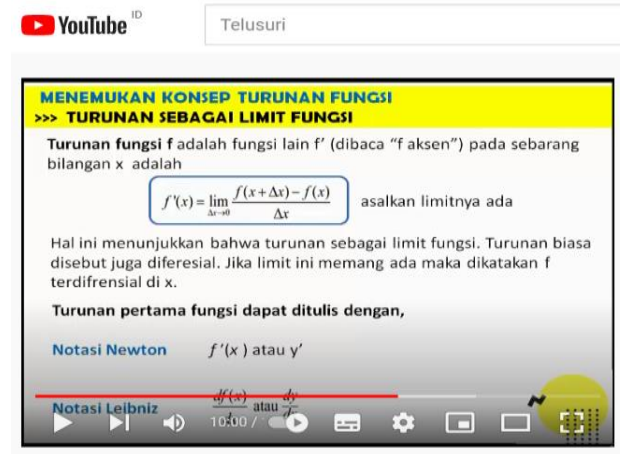

Turunan Fungsi Kelas XI

Gambar 6. Video materi turunan fungsi di youtube

Dengan tersedianya video ini diharapkan mampu memfasilitasi siswa untuk lebih mudah mengakses materi turunan fungsi. Suwarto et al., (2021) menyatakan bahwa video pembelajaran yang tersimpan di youtube dapat dimanfaatkan sebagai media pembelajaran interaktif di kelas yang setiap saat dapat diakses tanpa mengenal batas ruang dan waktu.

\section{KESIMPULAN DAN SARAN}

Desain video pembelajaran matematika materi turunan fungsi yang dikembangkan layak digunakan bagi siswa SMA Kelas IX. Hal ini karena desain video pembelajaran materi turunan memenuhi kriteria valid dari hasil validator dan mendapat respon sangat positif dari siswa. Video pembelajaran materi turunan fungsi dapat digunakan sebagai materi tambahan untuk belajar interaktif secara mandiri di sekolah atau di rumah dalam rangka untuk membangkitkan minat siswa dan memudahkan siswa dalam memahami turunan fungsi.

Pengembangan desain video pembelajaran ini hanya sebatas puji coba terbatas, belum dilaksanakan uji coba lebih luas, sehingga perlu dilakukan ujicoba di kelas untuk menguji keefektifan penggunaan video pembelajaran.

\section{UCAPAN TERIMAKASIH}

Ucapan terima kasih kami sampaikan kepada Direktorat Riset dan Pengabdian Masyarakat Direktorat Jenderal Penguatan Riset dan Pengembangan Kementerian Riset Teknologi/Badan Riset Inovasi Nasional yang telah memberikan dana penelitian melalui skema Penelitian Dosen Pemula (PDP) Tahun 2021.

\section{DAFTAR PUSTAKA}

Agustini, K., \& Ngarti, J. G. (2020). Pengembangan Video Pembelajaran Untuk Meningkatkan Motivasi Belajar Siswa Menggunakan Model R\&D. Jurnal Imiah Pendidikan dan Pembelajaran, 4(1), 17.

Agustiningsih, A. (2015). Video Sebagai Alternatif Media Pembelajaran dalam Rangka Mendukung Keberhasilan Penerapan Kurikulum 2013 di Sekolah Dasar. PEDAGOGIA: Jurnal Pendidikan, 4(1), 50. https://doi.org/10.21070/pedagogi a.v4i1.72.

Alamsyah, R., Toenlioe, A., \& Husna, A. (2018). Pengembangan Video Pembelajaran Kepenyiaran Materi Produksi Program Televisi Untuk Mahasiswa Teknologi Pendidikan Universitas Negeri Malang. JKTP: Jurnal Kajian Teknologi Pendidikan, 1(3), 229236.

Anjarsari, P., \& Karim, A. (2020). Analisis Video Pembelajaran Matematika Tingkat SMA Sederajat. Prosiding Seminar Nasional dan Diskusi Panel Pendidikan Matematika Universitas Indraprasta PGRI, Jakarta, 247-254. 
Eleanor, A., Uchenna, A., \& Aruchi, N. (2019). Assessment Of Instructional Media Use In Enhancing Teaching And Learning Of Accounting By Business Education Students In The Niger Delta, Nigeria. International Multidisciplinary Academic Research Journal, 3(1).

Fadhli, M. (2015). Pengembangan Media Pembelajaran Berbasis Video Kelas IV Sekolah Dasar. Jurnal Dimensi Pendidikan dan Pembelajaran, 3(1), 24-29. https://doi.org/10.24269/dpp.v3i1. 157

Farman, F. (2020). Development of Mathematics Learning Design through Problem Posing Approach for Developing Mathematical Reasoning Ability. Proceeding of USN Kolaka-ADRI International Conference on Sustainable Coastal-Community Development, $1(0), \quad 167-174$. https://doi.org/10.31327/icusnadri.vli0.1158

Farman, F., Arbain, A., \& Hali, F. (2021). Learning Style Preferences Based on Class and Gender. AL-ISHLAH: Jurnal Pendidikan, 13(1), 164-172. https://doi.org/10.35445/alishlah.v $13 \mathrm{i} 1.368$

Farman, F., \& Chairuddin, C. (2020). Pengembangan Media E-Learning Berbasis Edmodo Pada Materi Teorema Pythagoras. AKSIOMA: Jurnal Program Studi Pendidikan Matematika, $\quad 9(4), \quad 872$. https://doi.org/10.24127/ajpm.v9i 4.3114

Fatmanissa, N., Kusnandi, \& Usdiyana, D. (2019). Student difficulties in word problems of derivatives: A multisemiotic perspective. Journal of Physics: Conference
Series, $\quad 1157, \quad 032111$. https://doi.org/10.1088/17426596/1157/3/032111

Ferawati, E. (2021) Tingkat Partisipasi Siswa dalam Pembelajaran Daring Matematika di Era New Normal Menggunakan Video Youtube di Kelas VII SMPIT ANNIDA'Lubuklinggau. Lentera Sriwijaya, 3(1), 1-14.

Gusmania, Y., \& Dari, T. W. (2018). Efektivitas Penggunaan Media Pembelajaran Berbasis Video Terhadap Pemahaman Konsep Matematis Siswa. PYTHAGORAS: Jurnal Program Studi Pendidikan Matematika, $7(1)$.

https://doi.org/10.33373/pythagor as.v7i1.1196

Kurniadi, H. (2017). Pemanfaatan Media Video Pembelajaran Untuk Meningkatkan Hasil Belajar Matematika Materi Bangun Ruang Siswa Kelas IV SD Negeri Magersari 2 Magelang. E-Jurnal Skripsi Program Studi Teknologi Pendidikan, 6(5), 501-507.

Muhammad, H. (2020). Menyiapkan Pembelajaran di Masa Pandemi: Tantangan dan Peluang. Kementerian Pendidikan dan Kebudayaan. (https://spab.kemdikbud.go.id/wpcontent/uploads/2020/07/Menyiapk an-Pembelajaran-di-MasaPandemi-1.pdf)

Muna, H., Nizaruddin, N., \& Murtianto, Y. H. (2017). Pengembangan Video Pembelajaran Matematika Berbantuan Macromedia Flash 8 Dengan Pendekatan Kontekstual Pada Materi Program Linier Kelas XI. AKSIOMA, 8(2), 9. https://doi.org/10.26877/aks.v8i2.1 686

Nasrum, A., \& Herlina, H. (2019). Developing Of Calculus Teaching Materials Based On AudiovisuaL. 
DOI: https://doi.org/10.24127/ajpm.v10i4.4092

Infinity Journal, 8(2), 209-218. https://doi.org/10.22460/infinity.v8i 2.p209-218.

Nurfadhillah, S., Cahyani, A. P., Haya, A. F., Ananda, P. S., \& Widyastuti, T. (2021). Penerapan Media Audio Visual Berbasis Video Pembelajaran pada Siswa Kelas IV di SDN Cengklong 3. PANDAWA, 3(2), 396-418. https://doi.org/10.36088/pandawa.v 3i2.1272.

Octavyanti, N. P. L. (2021). Video Pembelajaran Berbasis Pendekatan Kontekstual Pada Mata Pelajaran Matematika Kelas IV SD. 8(1), 9.

Parlindungan, D. P., Mahardika, G. P., Yulinar, D. (2020). Efektivitas Media Pembelajaran Berbasis Video Pembelajaran dalam Pembelajaran Jarak Jauh (PJJ) di SD Islam An-Nuriyah. Prosiding Seminar Nasional Penelitian LPPM UMJ, 1-8

Purwanti, B. (2015). Pengembangan Media Video Pembelajaran Matematika dengan Model Assure. Jurnal Kebijakan dan Pengembangan Pendidikan, 3(1), 42-47.

Saloko, A., Jampel, I. N., \& Suwatra, I. W. (2013). Pengembangan Media Video Pembelajaran Mata Pelajaran Matematika Pada Siswa Kelas V SD Negeri 2 Seririt Tahun Pelajaran 2012/2013 Semester Ganjil. Journal of Education Technology, $1(2), \quad 11$. https://doi.org/httpdx.doi.org10.238 87jeu.v1i2.1501

Surat Edaran Nomor 4 Tahun 2020 Tentang Pelaksanaan Kebijakan Pendidikan Dalam Masa Darurat Penyebaran Corona Virus Disease (Covid-19). Kementerian Pendidikan dan Kebudayaan Republik Indonesia.

Suryansah, T., \& Suwarjo, S. (2016). Pengembangan Video
Pembelajaran Untuk Meningkatkan Motivasi Dan Hasil Belajar Kognitif Siswa KelaS IV SD. Jurnal Prima Edukasia, 4(2), 209.https://doi.org/10.21831/jpe.v4i 2.8393

Suwarto, S., Muzaki, A., Muhtarom, M. (2021). Pemanfaatan Media YouTube sebagai Media Pembelajaran pada Siswa Kelas XII MIPA di SMA Negeri 1 Tawangsari. Media Penelitian Pendidikan: Jurnal Penelitian dalam Bidang Pendidikan dan Pengajaran, 15 (1): 26-30.

Wardono, Waluya, S. B., Mariani, S., \& Candra D, S. (2016). Mathematics Literacy on Problem Based Learning with Indonesian Realistic Mathematics Education Approach Assisted E-Learning Edmodo. Journal of Physics: Conference Series, 693, 012014. https://doi.org/10.1088/17426596/693/1/012014. 